\title{
Effect of Bacillus and Trichoderma species in the management of the bacterial wilt of tomato (Lycopersicum esculentum) in the field
}

\author{
Caroline K. Kariuki* ${ }^{*}$, Eunice W. Mutitu and William M. Muiru
}

\begin{abstract}
Background: Bacterial wilt caused by Ralstonia solanacearum is one of the most devastating diseases in tomato cultivation. This study aimed to evaluate the effect of Bacillus and Trichoderma isolates to manage the bacterial wilt disease.

Main body of the abstract: Field experiments were conducted in a randomized complete block design at Mwea and Kabete sites in Kenya. The treatments included 3 Trichoderma; 2 Bacillus isolates; a mixture of T1, T2, and T4; chemical standard; and distilled water as control. Trichoderma and Bacillus isolates were grown on sterilized sorghum grain and cow manure carriers respectively. Antagonist's inoculation was carried out by dipping tomato plants for 30 min in each treatment suspension. Each treatment was then applied at a rate of $150 \mathrm{ml} /$ plant hole and this was repeated after 35 days. All the treatments significantly reduced bacterial wilt incidence and severity at $P \leq$ 0.05 than the control at both sites. Trichoderma isolate T1, followed by Bacillus isolate CB64, was the best in reducing the disease incidence by more than 61.66 and 53\%, respectively at both sites. Treatment CB64 and T1 had the highest reduction of $R$. solanacearum population in the soil by 93.17 and $92.07 \%$, respectively. However, control had a pathogen increase of 20.40\%. CB64 and T1 performed significantly better compared to the standard, while the mixture of isolates $\mathrm{T} 1, \mathrm{~T} 2$, and T4 performed the poorest in all parameters. The treatments also increased the yield of tomato.
\end{abstract}

Short conclusion: Results from this study showed that Trichoderma and Bacillus isolates are effective biological control agents for use in management of bacterial wilt.

Keywords: Biological control agents, Trichoderma, Bacillus isolates, Antagonists, Tomato, Ralstonia solanacearum

\section{Background}

Tomato (Lycopersicum esculentum) is one of the most consumed vegetables in Kenya (Smart Farm, 2016). Cultivation of tomato crop suffers high losses due to several viral, fungal, and bacterial diseases that affect the crop (Yuging, 2018). Among the diseases, bacterial wilt caused by Ralstonia solanacearum has been reported to be the most rampant disease in tomato production

\footnotetext{
* Correspondence: qarolkariuki@gmail.com

Department of Plant Science and Crop Protection, University of Nairobi, P.O. Box 29053-00625, Nairobi, Kenya
}

\section{Springer Open}

(Kago et al., 2019). In Kenya, bacterial wilt causes 64\% losses on crops grown under open field conditions and up to $100 \%$ loss on the crops in the greenhouse (Mbaka et al., 2013).

Management of bacterial wilt is difficult since $R$. solanacearum pathogen has a wide host range and damages over 200 plant species in 50 different families that include tomato, potato, eggplant, pepper, and tobacco (Meng, 2013). The pathogen has a high destructive nature, ability to persist even in abandoned lands, and a wide geographical distribution (tropics, sub-tropics, 
warm temperate regions) (Mihovilovich et al., 2017). There are hardly known chemicals to manage bacterial diseases, except antibiotics that are used for animal and human diseases (Yendyo et al., 2017). These antibiotics are highly regulated to avoid development of resistance if carelessly used.

The effectiveness of available conventional management strategies for bacterial wilt is very limited (Aguk et al., 2018). Hence, biological control measures that use antagonistic fungal and bacterial agents are an attractive option (Mandal et al., 2017). Biological control of bacterial wilt disease of solanaceous crops caused by $R$. solanacearum, using antagonistic agents, has been reported earlier (Singh, 2013 and Kumur, 2017). Plant growth promoting bacteria and fungi-like Bacillus and Trichoderma species have been reported to be promising biocontrol agents for management of $R$. solanacearum. It has been found that species of Bacillus and Trichoderma are able to reduce bacterial wilt incidence on tomato plants and increase the yields (Thongwai \& Kunopakarn, 2007 and Narasimhamurthy et al., 2018).

Hence, the aim of this present study was to evaluate the efficacy of Bacillus and Trichoderma strains in managing the bacterial wilt of tomato under field conditions.

\section{Methods}

\section{Experimental site}

The experiments were conducted during the period March-August 2019. Tomato fields heavily infected with bacterial wilt disease were identified at Mwea and Kabete sites. Kabete field station is located in Kenya at an agro-ecological zone (AEZ) III, at $01^{\circ} 15^{\prime} \mathrm{S}$; $036^{\circ} 44^{\prime}$ $\mathrm{E}$ and an altitude of $1820 \mathrm{~m}$ above sea level. It has a bimodal rainfall of $1059 \mathrm{~mm}$ annually, and temperature ranges between 12.3 and $22.5^{\circ} \mathrm{C}$. The soils are deep, dark brown to brown humic nitisols with kaolinite clay minerals and a good drainage ideal for tomato production. Mwea site, Kirinyaga County, is located in agroecological zones II at $0.5420^{\circ} \mathrm{S}, 37.2735^{\circ} \mathrm{E}$ and at an altitude of $1570 \mathrm{~m}$ above sea level. The region experiences a bimodal rainfall of $1470 \mathrm{~mm}$ annually, and temperature ranges between 15.6 and $28.6^{\circ} \mathrm{C}$. The soils are deep humic nitisols that are moderately fertile with a $\mathrm{pH}$ of about 5 (Waiganjo et al., 2006).

\section{Experimental design}

The experimental design was randomized complete block design (RCBD), with 8 treatments and 3 replicates. Each plot was $3.6 \times 2 \mathrm{~m}$, separated from other plot by 1 $\mathrm{m}$ of weed-free bare ground. The blocks were separated by $2-\mathrm{m}$ paths. Rio Grande tomato variety that is moderately resistant to bacterial wilt disease was used. There were 20 plants in each plot with a spacing of $60 \times 60$ $\mathrm{cm}$. The 8 treatments tested were Trichoderma isolates
T1, T2, and T4 isolated from Kabete field station, purified and each multiplied in a sorghum carrier. Bacillus isolates CB64 and CA7 were sourced from the department of Plant Science and Crop Protection at the University, and each was multiplied in cow manure carrier. A chemical standard used by farmers (di-bromo di nitro propane 1,3-diol) was also used. A mixture treatment of $\mathrm{T} 1$, T2, and T4 in the ratio of 1:1:1 was included, and distilled water was used as the control.

\section{Growth and survival of Bacillus isolates in cow manure carrier}

Two Bacillus isolates CB64 and CA7 that had the highest activity against $R$. solanacearum in vitro were multiplied in cow manure used as a carrier for field experiments. Cow manure, which had decomposed for a period of 3 months, was sun dried, crushed, and sieved through 2-mm sieve. The C:N ratio of the manure was determined before sterilization at $121{ }^{\circ} \mathrm{C}$ at 1.5 bars for $15 \mathrm{~min}$. This process of sterilizing manure was repeated once for 3 days. Two hundred grams of the sterile manure was poured in sterile sandwich boxes, used as incubating chambers. Isolates $\mathrm{CB} 64$ and $\mathrm{CA} 7$ previously grown on nutrient agar at $27^{\circ} \mathrm{C}$ for $48 \mathrm{~h}$ were harvested by flooding the plates of each isolate with $5 \mathrm{ml}$ sterile distilled water. Bacterial colonies were then scraped off, using sterile glass slides, and each Bacillus isolate suspension was emptied in different sterile conical flasks. The concentration of the bacterial suspension was adjusted to $1 \times 10^{9} \mathrm{CFU} / \mathrm{ml}$ by the serial dilution technique. Using a sterile pipette, $0.5 \mathrm{ml}$ of sterile distilled water was added to $1 \mathrm{~g}$ of the dry sterile cow manure to make it moist and to facilitate bacteria multiplication. Using a sterile syringe, the sterile manure was inoculated by injecting $0.3 \mathrm{ml}$ of each Bacillus suspension into $1 \mathrm{~g}$ of manure, following a modified protocol of Macharia (2002). Bacillus isolates were allowed to multiply in the carrier at $28^{\circ} \mathrm{C}$ for $48 \mathrm{~h}$. The concentration of Bacillus isolates in the manure was determined by serial dilution technique.

\section{Growth and survival of Trichoderma isolates in sorghum carrier}

Three Trichoderma isolates, T1, T2, and T4, that had the highest activity against $R$. solanacearum in vitro were maintained by regular sub-culturing at intervals of 10 days on PDA. The isolates were multiplied in white sorghum grains following a modified protocol of Kumar (2017). The C:N ratio of the sorghum grains was determined before sterilization. Two hundred and fifty grams of sorghum grain was placed in 1-L conical flask and supplemented with $5 \%$ anhydrous dextrose in $250 \mathrm{ml}$ distilled water. The sorghum was then parboiled and autoclaved at $121^{\circ} \mathrm{C}$ at 1.5 bars for $1 \mathrm{~h}$ for 2 consecutive 
days. Five-millimeter discs of 7-day old culture of each Trichoderma isolates were placed in each of the flasks with sterilized sorghum grains. The flasks were corked with cotton wool and aluminum foil then incubated at $28 \pm 1{ }^{\circ} \mathrm{C}$ for 18 days, with regular shaking after every 3 days. Colonized sorghum was air dried and ground into powder, using a grinding machine. Spore concentration per gram of the colonized sorghum grain carrier was determined on the 7th, 11th, 14th, and 18th day after inoculation, using the serial dilution technique of Muriungi et al. (2013).

Preparation and application of the treatments in the field One gram of well-colonized manure that contained 5.86 $\times 10^{15} \mathrm{CFU} / \mathrm{g}$ for Bacillus isolate CB64 and $6.73 \times 10^{15}$ $\mathrm{CFU} / \mathrm{g}$ for isolate CA7 was mixed each in $10 \mathrm{ml}$ distilled water. For each Trichoderma isolate, $1 \mathrm{~g}$ of wellcolonized ground sorghum that contained an average of $2.6 \times 10^{9}$ spores/g was mixed in $40 \mathrm{ml}$ distilled water. The mixture of $\mathrm{T} 1, \mathrm{~T} 2$, and $\mathrm{T} 4$ was prepared in a ratio of $1: 1: 1$, and the concentration applied was $2.6 \times 10^{9}$ spores/g of sorghum carrier. One gram of the standard chemical was mixed in $3 \mathrm{~L}$ of distilled water, following the manufacturer's recommended application rates. Four-week-old tomato plants were uprooted from the nursery. The roots of tomato plants were first dipped for $30 \mathrm{~min}$ in the treatments to ensure that the isolates were given enough time for interaction with the plants before being transplanted into the field. Immediately after transplanting, a soil drench of $150 \mathrm{ml}$ of each treatment was applied around the plant roots, following a modified protocol of Rosyidah et al. (2013). The soil drench with freshly prepared treatments was applied again after 35 days of transplanting.

\section{Determination of bacterial wilt incidence and severity}

Bacterial wilt incidence was assessed every week after treatment application up to the end of the experiment by counting the number of wilted plants in each plot. Disease incidence was assessed as percentage of wilted plants within each treatment,

$$
\text { i.e., } I=\frac{\text { NPSWS }}{\mathrm{NPPT}} \times 100
$$

where $I$ is the wilt incidence, NPSWS is the number of plant showing wilt symptoms, and NPPT is the number of plants per treatment (Ayana et al., 2011).

Assessment of the disease severity at the end of the experiment, 126 days after transplanting, was based on stem browning and bacterial ooze (Elphinstone et al., 1998). Any browning observed on the split stem was recorded, using a score of $0-3$ where $0-$ no browning, $1-$ light brown color restricted to $2 \mathrm{~cm}$ from base of stem, 2-light brown color spread more than $2 \mathrm{~cm}$ from the base of the stem, and 3-dark brown color on the vascular tissue. Bacterial ooze was scored at $0-3$ where $0-$ no ooze, 1-thin strands of bacteria ooze that stops in 3 min, 2-continuous thin flow that is unrestricted, and 3 -heavy ooze turning the water turbid in 2 min. Percentage severity index (PSI) was calculated, using the method described by Cooke (2006): PSI $=\Sigma$ (sores $\times$ $100) /($ number of plants rated $\times$ maximum scale of the scores).

\section{Effect of Bacillus and Trichoderma isolates on Ralstonia solanacearum population in the soil}

The pathogen's population was determined 3 times during the experiment. The first sampling was carried out before tomato plants were transplanted to determine the population of $R$. solanacearum in the experimental area. The second and third samplings were undertaken at 60 and 112 days after treatment application. Six plants were randomly sampled from each treatment to determine the population of $R$. solanacearum in the soil rhizosphere around the plant root zone. Scoops of about $50 \mathrm{~g}$ were randomly picked from a depth of $10 \mathrm{~cm}$ and were composited in polythene bags for laboratory analysis. Ten grams of the sampled soil was placed into $250-\mathrm{ml}$ flasks containing $90 \mathrm{ml}$ sterile water. After vigorous shaking for $30 \mathrm{~min}$ in a rotary shaker at $200 \mathrm{rpm}$, the suspension was serially diluted up to 7 -fold as described by Xu et al. (2012). One millimeter from each of the 6th and 7th dilutions was plated on Kelman's TZC media. After $48 \mathrm{~h}$ of incubation at $28^{\circ} \mathrm{C}$, colonies typical to $R$. solanacearum were counted. Colony-forming units were calculated per gram of soil.

\section{Effect of Bacillus and Trichoderma isolates on tomato yields and fruit size}

Tomato yields were assessed weekly from the first harvest of mature fruits at 85 days after transplanting by measuring the weight of the total fruit from each plot, using a weighing balance. The yields per plot were converted to tonnes per hectare (Diogo \& Wydra, 2007). The quality of tomato fruits was determined by measuring fruit diameter per plot, using Vernier caliper.

\section{Data analysis}

The experiments in this study were laid out in a randomized complete block design, and each experiment was repeated thrice. Data collected on bacterial wilt incidence, severity, and population of $R$. solanacearum in the soil was subjected to analysis of variance (ANOVA), using the Genstat statistical software 15th edition. ANOVA test was conducted in a general treatment structure in randomized block design to evaluate the significant differences due to treatments (biological control 
agents), between the test location (Kabete and Mwea site) and among the days after treatment application. Means were separated using Fisher's protected LSD at $5 \%$ significance level.

\section{Results and discussion}

\section{Growth and survival of Trichoderma isolates in sorghum} carrier

The study showed that Trichoderma isolates were able to grow, survive, and multiply in sorghum grain carrier (Table 1). Sporulation of each Trichoderma isolate in sorghum carrier started between 5 to 21 days after incubation. Colonization of the parboiled sorghum was characterized by the sorghum grains assuming whitish, yellow, and greenish color of the Trichoderma spp. Strains of Trichoderma are known to colonize substrates containing lignin and cellulose such as sorghum, rice, maize grains, and farmyard manure among others. They produce enzymes that degrade polysaccharides in sorghum and other substrates (Kumar, 2017).

Trichoderma isolate T4 gave the best growth as demonstrated by sporulation, followed by isolate T1 and then T2. Sporulation of all the Trichoderma isolates increased from $10^{6}$ to $10^{9}$ conidia per gram of sorghum carrier between 7 and 14 days of incubation. These findings are in agreement with those reported by Singh et al. (2014) that at 7 days after inoculation, sorghum grain substrate had the highest population of Trichoderma harzianum of $2.25 \times 10^{8} \mathrm{CFU} / \mathrm{g}$. The results herein are also comparable to those reported by Rajput et al. (2014) that the highest population of $10.03 \times 10^{9} \mathrm{CFU} / \mathrm{g}$ of $T$. harzianum was recorded from sorghum grain carrier compared to other substrates.

The C:N ratio of the white sorghum was 13.4. This ratio showed that there was a high nitrogen content in the sorghum carrier. The availability of $\mathrm{N}$ in sorghum carrier increased sporulation and hypha growth essential for substrate colonization, and this was in agreement with reports by Okoth et al. (2009). Similar findings by

Table 1 Mean no. of Trichoderma conidia per gram of carrier at $7,11,14$, and 18 days of incubation

\begin{tabular}{lllll}
\hline Treatment & \multicolumn{4}{l}{ Incubation period (days) } \\
\cline { 2 - 5 } & $\mathbf{7}\left(\times \mathbf{1 0}^{\mathbf{6}}\right)$ & $\mathbf{1 1}\left(\times \mathbf{1 0}^{\mathbf{8}}\right)$ & $\mathbf{1 4}\left(\times \mathbf{1 0}^{\mathbf{9}}\right)$ & $\mathbf{1 8}\left(\times \mathbf{1 \mathbf { 0 } ^ { \mathbf { 9 } } )}\right.$ \\
\hline Trichoderma isolate T1 & $8.10 \mathrm{~b}$ & $9.70 \mathrm{a}$ & $2.70 \mathrm{a}$ & $2.60 \mathrm{a}$ \\
Trichoderma isolate T2 & $60.00 \mathrm{a}$ & $3.60 \mathrm{ab}$ & $1.10 \mathrm{~b}$ & $0.98 \mathrm{~b}$ \\
Trichoderma isolate T4 & $0.01 \mathrm{C}$ & $0.69 \mathrm{~b}$ & $5.50 \mathrm{a}$ & $5.50 \mathrm{a}$ \\
Mean & 22.70 & 4.70 & 3.10 & 3.03 \\
CV (\%) & 13.9 & 67.6 & 60.2 & 62.1 \\
LSD & 6.30 & 6.30 & 3.73 & 3.75 \\
\hline
\end{tabular}

Means that have the same letter(s) along a column are not significantly different at $P \leq 0.05$. The LSD of the interaction between treatments and days was 2.25
Srivastava et al. (2010) also reported that out of 6 substrates used for mass multiplication of $T$. harzianum, sorghum grains that had high $\mathrm{N}$ content was the best carrier and gave significantly higher numbers of Trichoderma conidia than other substrates. Obtained results showed that sorghum grain was a good substrate for multiplication and use as a carrier for Trichoderma isolates for large application of the isolates in the field. These results herein confirm those reported by Kumar (2017). However, from 14 to 18 days of incubation, the concentration of Trichoderma isolates $\mathrm{T} 4$ and $\mathrm{T} 1$ remained constant at $10^{9}$ conidia/g of sorghum, while for the isolate $\mathrm{T} 2$, the conidia concentration reduced slightly to $10^{8}$. These results are comparable to the findings reported by Muriungi et al. (2013) who found that there was an increase in Trichoderma isolates conidia per gram of sorghum carrier but the increase was not indefinite. These results indicated that 2 weeks was enough to give maximum spore concentration of the Trichoderma isolates in sorghum carrier. This is because with time, when the available nutrients in sorghum substrate are exhausted, the population of Trichoderma remains constant or falls rapidly (Singh et al. 2014).

\section{Determination of bacterial wilt incidence and severity in Kabete and Mwea fields}

All treatments showed significantly lower disease incidences and severity than the control at $P \leq 0.05$ (Table 2). A minimum disease incidence (26.67\%) was observed after 126 days of incubation in plots treated with Trichoderma isolate T1 at both Kabete and Mwea sites. This performance was significantly better than control plots that gave 88.33 and 93\% disease incidence at Kabete and Mwea site, respectively. These results are in agreement with Kumar (2017) who reported tomato bacterial wilt disease incidence range of $30-40 \%$, when plots were treated with $T$. harzianum. The best treatment, Trichoderma isolate T1, which had more than $61.66 \%$ reduction of bacterial wilt disease incidence also gave the lowest disease severity of 63.33\% than the control (98\%) severity index at both sites. The percentage severity observed in $\mathrm{T} 1$ was lower than control plots by more than $47 \%$. These findings are in line with Narasimhamurthy et al.'s (2018) reports that $T$. asperellum-treated plots showed a reduction of bacterial wilt disease by $51.06 \%$. Rosyidah et al. (2013), Tinatin and Saykal (2016), and Yendyo et al. (2017) confirmed the same results. The reduction of bacterial wilt incidence and severity may be due to Trichoderma strains producing antagonistic compounds against $R$. solanacearum. These findings are in line with Tapwal et al. (2011) who reported that different strains of Trichoderma produce various metabolites and secondary compounds that have antagonistic activity against $R$. solanacearum. 
Table 2 Disease incidence assessed as percentage of wilted plants within each treatment days after transplanting

\begin{tabular}{|c|c|c|c|c|c|c|c|c|c|c|}
\hline \multirow[b]{2}{*}{ Treatment } & \multicolumn{5}{|l|}{ Kabete } & \multicolumn{5}{|l|}{ Mwea } \\
\hline & 61 days & 85 days & 98 days & 112 days & 126 days & 61 days & 85 days & 98 days & 112 days & 126 days \\
\hline $\mathrm{T1}$ & $6.70 a$ & $11.67 a$ & $21.67 a$ & $26.67 a$ & $26.67 a$ & $8.33 a$ & $13.33 a$ & $23.33 a$ & $25.00 a$ & $26.67 a$ \\
\hline CB64 & $6.70 a$ & $11.67 a$ & $23.33 a$ & $28.33 a$ & $30.00 a$ & $8.33 a$ & $15.00 \mathrm{a}$ & $23.33 a$ & $28.33 a$ & $40.00 \mathrm{~b}$ \\
\hline $\mathrm{T} 2$ & $6.70 a$ & 16.67abc & $28.33 a$ & $46.67 b$ & $50.00 \mathrm{~b}$ & 11.76ab & $16.67 a$ & $25.00 \mathrm{a}$ & $43.33 b$ & $50.00 c$ \\
\hline Standard & $8.30 \mathrm{a}$ & 15.00ab & $30.00 a$ & $46.67 \mathrm{~b}$ & $50.00 \mathrm{~b}$ & $16.67 \mathrm{bc}$ & $30.00 \mathrm{~b}$ & $43.33 b$ & $46.67 b$ & $51.67 c$ \\
\hline $\mathrm{T} 4$ & $8.30 a$ & $21.67 a b c$ & $33.33 a b$ & $46.67 b$ & $51.67 \mathrm{~b}$ & $21.67 \mathrm{~cd}$ & $28.33 b$ & $45.00 \mathrm{bc}$ & $48.33 b c$ & $51.57 c$ \\
\hline CA7 & $11.70 \mathrm{a}$ & $28.33 \mathrm{bcd}$ & $43.33 b c$ & $55.00 \mathrm{c}$ & $76.67 c$ & $25.00 \mathrm{~d}$ & $41.67 c$ & $48.33 c$ & $53.33 c$ & $73.33 d$ \\
\hline $\mathrm{T} 1, \mathrm{~T} 2$, and $\mathrm{T} 4 \mathrm{mix}$ & 18.30ab & $30.00 \mathrm{~cd}$ & $46.67 \mathrm{~cd}$ & $68.33 d$ & $83.33 d$ & $36.67 e$ & $56.67 d$ & $71.67 d$ & $83.33 d$ & $88.33 e$ \\
\hline Control & $23.30 \mathrm{~b}$ & $40.00 \mathrm{~d}$ & $58.33 d$ & $75.00 \mathrm{e}$ & 88.33e & $46.67 f$ & 66.67e & 76.67e & 86.67de & $93.33 f$ \\
\hline Mean & 11.2 & 21.9 & 35.6 & 49.17 & 57.08 & 21.88 & 33.54 & 44.58 & 51.88 & 59.38 \\
\hline$\% C V$ & 60.1 & 35.1 & 19 & 6.3 & 4.1 & 21.7 & 8.4 & 5.5 & 6.3 & 4.4 \\
\hline LSD & 11.84 & 13.46 & 11.86 & 5.45 & 4.05 & 8.33 & 4.92 & 4.33 & 5.7 & 4.53 \\
\hline
\end{tabular}

Means that have similar letter(s) along a column are not significantly different at $P \leq 0.05$

Bacillus isolate CB64 was the second best treatment that showed bacterial wilt incidence of $30 \%$ at Kabete and $40 \%$ at Mwea after 126 days of transplanting. These findings are comparable to those reported by Singh et al. (2012) that a minimum disease incidence of $12.67 \%$ at 50 days after incubation was observed in Bacillus BS-5 treated soil. Similarly, in the present study, a disease incidence of $6.7 \%$ was recorded 60 days after plots were treated with Bacillus isolate CB64. Treatment CB64 had an average of $50 \%$ reduction in bacterial wilt incidence than the control. This was similar to earlier reports by Lemessa and Zeller (2007) that Bacillus subtilis strain $\mathrm{B}_{2} \mathrm{G}$ reduced bacterial wilt incidence by $60 \%$. Akintokun et al. (2019) also reported similar findings. Plots treated with $\mathrm{CB} 64$ had the lowest disease severity at an average of $59.46 \%$ than the control. Comparable findings were reported by Wei et al. (2011) and Huang et al. (2014) of the ability of Bacillus strains to produce various metabolites and compounds that are able to reduce bacterial wilt incidence and severity in tomato plants.

Plots treated with Trichoderma isolate T1 and Bacillus isolate CB64 performed better than plots treated with the standard chemical in reducing bacterial wilt disease incidence and severity (by more than 20\%). These findings were similar to those reported by Yendyo et al. (2017) that the best treatment outperformed the chemical control by more than $3 \%$ in reducing the disease. Plots treated with Trichoderma isolates T1, T2, and T4 had significantly lower (by more than 32\%) disease incidence and severity compared to plots treated with the mixture of the same treatments at both sites. These results agree to those reported by Akrami et al. (2011) that the mixture of $T$. asperellum, virens, and T. harzianum performed significantly lower in reducing Fusarium oxysporum disease severity compared to the same isolates applied individually. According to $\mathrm{Xu}$ et al. (2010), application of Trichoderma isolates as a mixture gave poor results in reducing disease incidence and severity of Botrytis cinerea compared to the same isolates applied individually. This is because each Trichoderma isolate produces antimicrobial compounds that might inhibit any BCA that they are applied in combination with, hence, may cause interference among the BCAs leading to the observed results. These findings support the results observed in the present study. However, further studies are needed to be carried out to test possible synergistic and antagonistic effects of the mixture of Trichoderma isolates.

Bacterial wilt disease incidence and severity progressed significantly faster at Mwea than Kabete site during the experiments. The mean difference between the 2 sites showed that Mwea site had higher disease incidence and severity by more than (7.26 and $8.30 \%)$, respectively than at Kabete site. This is because Mwea site located in AEZ II had higher temperatures than at Kabete site located at AEZ III. Higher maximum temperatures that ranged from 26 to $31.3^{\circ} \mathrm{C}$ were recorded at Mwea site and those of Kabete site ranged from 20.41 to $26^{\circ} \mathrm{C}$. High temperatures and moisture favor the growth of $R$. solanacearum. This explains the significant difference in the results observed in the two sites. These findings are similar to those reported by Yendyo et al. (2017).

\section{Effect of Bacillus and Trichoderma isolates on Ralstonia solanacearum population in the soil}

At the onset of the experiments, the amount of $R$. solanacearum inoculum in the soil was an average of $9.08 \times$ $10^{6} \mathrm{CFU} / \mathrm{ml}$ at Kabete and $1.05 \times 10^{8} \mathrm{CFU} / \mathrm{ml}$ at Mwea sites. This level of inoculum was able to cause 23.30 and $46.67 \%$ disease incidence on control plots at Kabete and Mwea sites, respectively 60 days after transplanting. These findings confirm those reported by Pradhanang 
et al. (2003) who found that $R$. solanacearum initial inoculum containing $4.5 \times 10^{6} \mathrm{CFU} / \mathrm{ml}$ was able to cause $100 \%$ bacterial wilt incidence in control plots at the end of the experiment. However, at 60 days after treatment application, all plots treated with Bacillus, Trichoderma, and standard chemical showed a significant reduction in $R$. solanacearum population in the soil at $P \leq 0.05$ than in the control at both Kabete and Mwea sites (Table 3). Just like in bacterial wilt incidence and severity reduction, plots treated with Bacillus isolate CB64 and Trichoderma isolate $\mathrm{T} 1$ gave the highest percentage reduction of the pathogen population in the soil of 93.17 and $92 \%$, respectively at Kabete site. At Mwea site, the reduction was $92 \%$ by Trichoderma $\mathrm{T} 1$ and $88.78 \%$ by CB64. Towards the end of the experiment, after 112 days of treatment application, all the treated plots gave more than $50 \%$ reduction of $R$. solanacearum population in the soil. Control plots gave $20 \%$ increase of the pathogen population at both sites. The results herein are similar to those reported by Sharma and Kumar (2009) that plots treated with Trichoderma viride reduced $R$. solanacearum population in the soil by $29 \%$ at 90 days of treatment application. Similar studies of Rosyidah et al. (2013) have reported that soil application of Trichoderma strains significantly reduced the population of $R$. solanacearum in the soil. The pathogen reduction in the soil may be attributed to Trichoderma strains that have the ability to adapt in extreme soil conditions. This adaptation allows Trichoderma spp. to colonize the soils, outcompete, and suppress the pathogen. According to studies by Sharma and Kumar (2009) strains of Trichoderma produces antibiotics like dermadine and gliotoxins that are able to suppress the development of bacterial pathogens such as $R$. solanacearum.
The antagonism between bacterial inoculum of Bacillus strains and $R$. solanacearum that occurs in the rhizosphere of tomato plant explains why there was reduction of the pathogen population in plots treated with Bacillus isolates. Comparable findings have reported more than $64 \%$ reduction of the pathogen population, when the soils were treated by Bacillus fortified organic fertilizer (Wei et al., 2011). Also, studies of Huang et al. (2014) reported that application of Bacillus amyloliquefaciens strongly reduced $R$. solanacearum population in the soil rhizosphere.

Plots treated with Trichoderma isolate T1 and Bacillus CB64 recorded more than 25\% reduction of $R$. solanacearum population in the soil than the chemical standard at both sites. These results are in line with Sharma and Kumar (2009) findings that soil drench with chemical treatment reduced bacteria pathogen population in the soil by only $36.2 \%$ at 90 days. Plots treated with the mixture of T1, T2, and T4 gave an average increase of $R$. solanacearum population of $2 \%$ at both Kabete and Mwea sites. This mixture of Trichoderma isolates performed poorly than the same isolates applied as individual treatments. These results are comparable to Guo et al. (2004) findings who reported that mixing strains of Trichoderma provided significantly lower suppression of bacterial wilt disease in the soil than the same isolates applied individually.

The trend of the results observed in the performance of all the treatments in reducing the pathogen population in the soil was in harmony with the findings recorded for the disease incidence and severity reduction. This was especially in plots treated with Trichoderma isolate T1 and Bacillus isolate CB64 that performed best in all the parameters. Plots that had a high percentage

Table 3 Quantification of Ralstonia solanacearum population in the soil after application of treatments $(\times 106)$ in CFU/ml

\begin{tabular}{|c|c|c|c|c|c|c|c|c|c|c|}
\hline \multicolumn{6}{|l|}{ Kabete } & \multicolumn{5}{|l|}{ Mwea } \\
\hline \multirow[b]{2}{*}{ Treatment } & \multirow[b]{2}{*}{ Before } & \multirow[b]{2}{*}{60 days } & \multirow[b]{2}{*}{112 days } & \multicolumn{2}{|c|}{$\%$ inoculum reduction } & \multirow[b]{2}{*}{ Before } & \multirow[b]{2}{*}{60 days } & \multirow[b]{2}{*}{112 days } & \multicolumn{2}{|c|}{$\%$ inoculum reduction } \\
\hline & & & & 60 days & 112 days & & & & 60 days & 112 days \\
\hline $\mathrm{T} 1$ & $9.83 a$ & $5.93 a$ & $0.78 a$ & $40.14 b$ & $92.07 a$ & $110.00 a$ & $55.67 a$ & $7.97 a$ & $49.57 a$ & $92.75 a$ \\
\hline CB64 & $9.57 \mathrm{a}$ & $4.77 a$ & $0.65 a$ & $50.44 a$ & $93.17 a$ & 108.00a & $70.00 \mathrm{ab}$ & $12.47 a$ & $35.51 b$ & $88.78 a$ \\
\hline $\mathrm{T} 2$ & 8.93ab & $6.43 a$ & $2.93 b$ & $27.89 \mathrm{c}$ & $67.34 b$ & 107.00a & $79.00 \mathrm{bc}$ & $33.00 \mathrm{~b}$ & $26.12 c$ & $68.47 b$ \\
\hline Standard & $9.07 a$ & $5.90 a$ & $3.20 b$ & $35.51 b c$ & $65.61 b$ & $110.00 \mathrm{a}$ & $86.67 \mathrm{bc}$ & $47.67 c$ & $21.69 \mathrm{~cd}$ & $56.92 \mathrm{C}$ \\
\hline $\mathrm{T} 4$ & $9.73 a$ & $8.33 b$ & $4.20 \mathrm{~b}$ & $14.31 d$ & $56.94 c$ & 104.30a & $78.67 \mathrm{bc}$ & $40.67 b c$ & $24.75 c$ & $61.37 b c$ \\
\hline CA7 & $9.07 a$ & $8.53 b$ & $8.30 c$ & $6.25 \mathrm{de}$ & $8.96 d$ & 108.70a & $91.67 \mathrm{~cd}$ & $76.00 d$ & $15.83 d$ & $29.82 d$ \\
\hline T1, T2, T4 Mix & $9.03 a$ & $9.20 \mathrm{~b}$ & $9.20 c$ & $-1.85 e$ & $-1.82 \mathrm{e}$ & 105.30a & 107.00d & 108.33e & $-1.92 \mathrm{e}$ & $-3.15 e$ \\
\hline Control & $7.37 b$ & $8.63 b$ & $8.87 c$ & $-17.11 f$ & $-20.40 f$ & $87.70 b$ & $94.00 \mathrm{~cd}$ & 106.00e & $-7.31 f$ & $-20.89 f$ \\
\hline Mean & 9.08 & 7.22 & 4.77 & 19.45 & 45.23 & 105.1 & 82.8 & 54 & 20.53 & 46.76 \\
\hline$\% C V$ & 11.6 & 14.6 & 16.7 & 25.8 & 10.4 & 10.1 & 11.7 & 12.4 & 24.6 & 12.9 \\
\hline LSD & 1.84 & 1.85 & 1.4 & 8.79 & 8.25 & 18.65 & 17.03 & 11.74 & 8.83 & 10.58 \\
\hline
\end{tabular}

Means that have similar letter(s) along a column are not significantly different at $P \leq 0.05$ 
reduction of $R$. solanacearum population in the soil also had low bacterial wilt incidence and severity. This is because there is a positive and significant correlation between the disease incidence and the pathogen population in the soil. These findings are in agreement to those reported earlier (Wei et al., 2011) that plots treated with Bacillus-fortified organic fertilizer had significantly reduced $R$. solanacearum populations in the soil and hence the plots had decreased disease incidence compared to the control.

Cow manure and sorghum grains were used as carriers for Bacillus and Trichoderma isolates, respectively. These carriers are known to provide beneficial strains in the soil with abundant nutrients that aid in their survival, production of antibiotics, and in suppressing soil pathogens such as $R$. solanacearum. This could explain why isolates of Bacillus and Trichoderma significantly reduced the pathogen population in the soil compared to control. These findings are comparable to those reported by Tan et al. (2013) that use of organic substrates like manure, rice husks, and sorghum or rice grains as carriers for BCAs can provide nutrients for the desired antagonists. This, therefore, increases their opportunity for establishment in the soil, which then increases their effectiveness.

\section{Effect of Bacillus and Trichoderma isolates on tomato yields and fruit size}

All treatments had significantly higher yields and fruit sizes than the control at $P \leq 0.05$. The average yields observed in plots treated with Bacillus isolate CB64 were 231.76 and $266.67 \%$ more than the control at Kabete and Mwea site, respectively. Seleim et al. (2011) reported similar findings that Bacillus subtilis and Pseudomonas fluorescence achieved 91 and 348\% increase of tomato yields per plant, respectively than the control. These yield results showed that the treatment with Bacillus isolate CB64 had the highest yield than the control. Comparable findings of Bacillus strains ability to promote growth and yields of tomato plants have been reported (Lemessa \& Zeller, 2007 and Yendyo et al., 2017).

In Trichoderma T1-treated plots, the average yields observed were 345.45 and $153.53 \%$ more than the control at Kabete and Mwea site, respectively. These results agree with that of Sharma and Kumar (2009) who reported a $142.1 \%$ increase of tomato yield than the control after application of Trichoderma viride in the soil. Kumar (2017) and Narasimhamurthy et al. (2018) also confirmed the results given herein. Not only were the fruit yields significantly higher, the fruit sizes in plots treated with CB64 and T1 were significantly higher by more than $62.60 \%$ than the control $(27.46 \mathrm{~mm})$ at both sites. Strains of Bacillus and Trichoderma are known to produce plant growth hormones that are responsible for increased yields and fruit size (Seleim et al. 2011 and Singh et al., 2012). Isolate CB64 and T1 also outperformed the standard chemical in yields and fruit sizes. The mixture of Trichoderma isolates was among the treatments that recorded the least yields and fruit size than the same isolates applied individually.

\section{Conclusion}

Bacillus isolates CB64 and Trichoderma isolate T1 had the highest percentages of reduction in bacterial wilt incidence and severity in the field. The isolates were also able to reduce the population of $R$. solanacearum in the soil by more than $90 \%$ than the control. Therefore, they are recommended for use as biological control agents in management of bacterial wilt disease caused by $R$. solanacearum of tomato. As well, cow manure and sorghum grains can be used as carriers for Bacillus and Trichoderma isolates, respectively.

\section{Abbreviations}

BCAs: Biological control agents; AEZ: Agro-ecological zones; ZOI: Zones of inhibition; CFU: Colony-forming units; PDA: Potato dextrose agar

\section{Acknowledgements}

The authors are grateful to the University of Nairobi, National Research Funds for providing financial support to conduct various experiments.

\section{Authors' contributions}

All the authors jointly designed the experiments. CKK conducted the experiment, performed data analysis, and drafted the manuscript with inputs from all the authors. EWM isolated the Bacillus isolates used. EWM and WMM supervised the experiment and reviewed the manuscript. All authors read and approved the final manuscript.

\section{Funding}

The National Research Funds (NRF) funded this research. The funder had no role in study design, data collection and analysis, decision to publish, or preparation of the manuscript.

\section{Availability of data and materials}

The data used and analyzed during this study is available from the corresponding author on request.

Ethics approval and consent to participate Not applicable

Consent for publication

Not applicable

\section{Competing interests}

The authors declare that they have no competing interests

Received: 3 June 2020 Accepted: 31 August 2020

Published online: 10 September 2020

\footnotetext{
References

Aguk JA, Karanja N, Schulte-Geldermann E, Bruns C, Kinyua Z, Parker M (2018) Control of bacterial wilt (Ralstonia solanacearum) in potato (Solanum tuberosum) using rhizobacteria and arbuscular mycorrhiza fungi. African J Food Agric Nutr Dev 18:13371-13387

Akintokun AK, Ojesola CO, Akintokun PO, Oloyede AR (2019) Antagonistic effect of Bacillus thuringiensis for the control of bacterial wilt of tomato (Lycopersicum esculentum). Nig J Biotech 36:94-102

Akrami M, Golzary H, Ahmadzadeh M (2011) Evaluation of different combination of Trichoderma species for controlling fusarium rot of lentil. Afr J Biotechnol 10:2653-2658
} 
Ayana G, Fininsa C, Ahmed S, Wydra K (2011) Effects of soil amendment on bacterial wilt caused by Ralstonia solanacearum and tomato yields in Ethiopia. J Plant Protect Res 51:72-76

Cooke BM (2006) Disease assessment and yield loss. p. 43-80. In: Cooke BM, Jone DG, Kaye B (eds) The epidemiology of plant diseases, 2nd edn. Springer, Dorchert, $576 \mathrm{pp}$

Diogo RVC, Wydra K (2007) Silicon-induced basal resistance in tomato against Ralstonia solanacearum is related to modification of pectic cell wall polysaccharide structure. Physiol Mol Plant Pathol 70:120-129

Elphinstone JG, Stanford HM, Stead DE (1998) Detection of Ralstonia solanacearum in potato tubers, Solanum dulcamara and associated irrigation water. In: Bacterial wilt disease. Springer, Berlin, Heidelberg, pp 133-139

Smart Farm (2016) History of tomatoes. Vegetable facts. Retrieved from http:// www.vegetablefacts.net/vegetable-history/history-of-tomatoes/

Guo JH, Qi HY, Guo YH, Ge HL, Gong LY, Zhang LX, Sun PH (2004) Biocontrol of tomato wilt by plant growth-promoting rhizobacteria. Biol Control 29:66-72

Huang J, Wei Z, Tan S, Mei X, Shen Q and Xu Y (2014) Suppression of bacterial wilt of tomato by bioorganic fertilizer made from the antibacterial compound producing strain Bacillus amyloliquefaciens HR62. Agric. Food Chem.

Kago EK, Kinyua ZM, Maingi JM, \& Okemo PO (2019) Control of Ralstonia solanacearum on selected solaneceous crop in greenhouse by selected soil amendments. Journal of Agriculture and Ecology Research International, 1-12.

Kumar N (2017) Occurrence and distribution of tomato diseases and evaluation of bio-efficacy of Trichoderma harzianum on growth and yield components of tomato. Nigerian J Agric Food Environ 13:37-44

Lemessa F, Zeller W (2007) Screening of rhizobacteria for biological control of Ralstonia solanacearum in Ethiopia. Biol Control 42:336-344

Macharia I. (2002). Biological control of root-knot nematodes (Meloidogyne spp) in common bean using Bacillus spp. Diss. Masters of Science thesis. University of Nairobi Kenya.

Mandal H, Chakraborty P, Das S, Saha A, Sarkar T, Saha D, Saha A (2017) Biocontrol of virulent Ralstonia solanacearum isolates by an indigenous Bacillus cereus. J Agric Technol 13:19-30

Mbaka JN, Gitonga JK, Gathambari CW, Mwangi BG, Githuka P, Mwangi M (2013) Identification of knowledge and technology gaps in high tunnels tomato production in Kirinyaga and Embu counties.

Meng F (2013) Ralstonia solanacearum species complex and bacterial wilt disease. J Bacteriol Parasitol 04(02). https://doi.org/10.4172/2155-9597.1000e119

Mihovilovich E, Lopes C, Gutarra L, Linqvist-kreuze H, Aley P, Priou S, Bonierbale M (2017) Protocol for assessing bacterial wilt resistance in greenhouse and field conditions. International co-operators' guide. Lima (Peru). International potato center. Isbn 978-92-9060-214-9. 35 p.

Muriungi JS, Mutitu EW, Siboe MG (2013) Bio control of fusarium root rot in beans by antagonistic Trichoderma fungi. Int J Agric Sci 3(7):550-557

Narasimhamurthy K, Krishnamurthy S, Siddaiah CN, Ramachandrappa NS, Srinivas C (2018) Evaluation of biological efficacy of Trichoderma asperellum against tomato bacterial wilt caused by Ralstonia solanacearum. Egyptian J Biol Pest Control 28:63

Okoth SA, Okoth P, Muya E (2009) Influence of soil chemical and physical properties on occurrence of Trichoderma spp. in Embu, Kenya. Trop Subtropical Agro Ecosystems 11:303-312

Pradhanang PM, Momol MT, Olson SM, Jones JB (2003) Effect of plant essential oils on Ralstonia solanacearum population density and bacterial wilt incidence in tomato. Plant Dis 87:423-427

Rajput AQ, Khanzada MA, Shahzad S (2014) Effect of different organic substrates and carbon and nitrogen sources on growth and shelf life of Trichoderma harzianum. Agr Sci Tech 16:731-745

Rosyidah A, Wardiyati T, Abadi AL, Maghfoer MD (2013) Enhancement in effectiveness of antagonistic microbes by means of microbial combination to control Ralstonia solanacearum on potato planted in middle latitude. Agrivita. 35:174-185

Seleim MAA, Saead FA, Abd-El-Moneem KMH, Abo-Elyousr KAM (2011) Biological control of bacterial wilt of tomato by plant growth promoting rhizobacteria. Plant Pathol J 24:221-233

Sharma JP, Kumar S (2009) Management of Ralstonia wilt of tomato through microbes, plant extract and combination of cake and chemicals. Indian Phytopath. 62:417-423

Singh AS, Panja B, Shah J (2014) Evaluation of suitable organic substrates based Trichoderma harzianum formulation for managing Rhizoctonia solani causing collar rot disease of cowpea. Int J Curr Microbiol App Sci 3:127-134
Singh D, Yadav DK, Sinha S, Upadhyay BK (2012) Utilization of plant growth promoting Bacillus subtilis isolates for the management of bacterial wilt incidence in tomato caused by Ralstonia solanacearum race 1 biovar 3 . Indian Phytopath 65:18-24

Singh JS (2013) Plant growth promoting Rhizobacteria. Resonance 18(3):275-281

Srivastava R, Khalid A, Singh US, Sharma AK (2010) Evaluation of Arbuscular mycorrhizal fungus, fluorescent pseudomonas and Trichoderma harzianum formulation against Fusarium oxysporum f. sp. lycopersici for the management of tomato wilt. Biol Control 53:24-31

Tan S, Jiang Y, Song S, Huang J, Ling N, Xu Y (2013) Two Bacillus amyloliquefaciens strains isolated using competitive tomato root enrichment method and their effects on suppressing Ralstonia solanacearum and promoting tomato growth. Crop Prot 40:134-140

Tapwal A, Singh U, Singh G et al (2011) In vitro antagonism of Trichoderma viride against five phytopathogens. Pest Technology 5:59-62

Thongwai N, Kunopakarn J (2007) Growth inhibition of Ralstonia solanacearum PT1J by antagonistic bacteria isolated from soils in northern part of Thailand. Chiang Mai J Sci 34:345-354

Tinatin D, Saykal B (2016) Identification of Ralstonia solanacearum in Kyrgyzstan's potato fields and the possibility of using biocontrol agents against this pathogen. Int J Environ and Agr Res 2:146-155

Waiganjo MM, Wabule NM, Nyongesa D, Kibaki JM, Onyango I, Wepukhulu SB, Muthoka NM (2006) Tomato production in Kirinyaga district, Kenya, a baseline survey report. Kenya Agricultural Research Institute, Nairobi, Kenya, pp 1-43

Wei Z, Yang XM, Yin SX, Shen QR, Ran W, Xu YC (2011) Efficacy of Bacillusfortified organic fertilizer in controlling bacterial wilt of tomato in the field. Appl Soil Ecol 48:152-159

Xu W-M, Han F-F, He M, Hu D-Y, He J, Yang S, Song B-A (2012) Inhibition of tobacco bacterial wilt with sulfone derivatives containing a 1, 3, 4oxadiazole moiey. J Agric Food Chem 60:1036-1041

Xu X-M, Robinson JD, Jeger M, Jeffries P (2010) Using combination of biocontrol agents to control Botrytis cinerea on strawberry leaves under fluctuating temperatures. Biocontrol Sci Tech 20:359-373

Yendyo S, Ramesh GC, and Pandey BR (2017) Evaluation of Trichoderma spp., Pseudomonas fluorescence and Bacillus subtilis for biological control of Ralstonia wilt of tomato. F1000research, vol. 6, p. 2028.

Yuging W (2018) Breeding for resistance to tomato bacterial diseases in China: challenges and prospects. Horticultural Plant J 4:193-207

\section{Publisher's Note}

Springer Nature remains neutral with regard to jurisdictional claims in published maps and institutional affiliations.

\section{Submit your manuscript to a SpringerOpen ${ }^{\circ}$ journal and benefit from:}

- Convenient online submission

- Rigorous peer review

- Open access: articles freely available online

High visibility within the field

- Retaining the copyright to your article

Submit your next manuscript at $>$ springeropen.com 